\title{
乙烷核态池沸腾中的气泡生长、脱离和上升
}

姚远 ${ }^{1,2}$, 公茂琼 ${ }^{1,2^{*}}$, 陈汉梽 ${ }^{1,2}$, 陈高飞 ${ }^{1}$, 邹金金 ${ }^{1}$, 董学强 ${ }^{1}$, 沈俊 ${ }^{1,2}$

1. 中国科学院理化技术研究所低温工程重点实验室, 北京 100190 ;

2. 中国科学院大学, 北京 100049

* 联系人, E-mail: gongmq@mail.ipc.ac.cn

2017-05-24 收稿, 2017-08-18 修回, 2017-08-21 接受, 2017-09-29 网络版发表

国家自然科学基金(51625603)和北京市自然科学基金(3171002)资助

摘要利用高速摄影仪对乙烷在水平铜表面饱和核态池沸腾中的气泡行为特性进行了实验研究, 并开展了理论 分析, 实验测量压力为 $0.2 \mathrm{MPa}$, 热流密度范围为14.65 80.79 $\mathrm{kW} \mathrm{m}^{-2}$. 实验中观测到气泡的生长、脱离和上升过 程, 得到单个气泡的生长周期, 同时绘制出单个气泡生长周期内的直径变化曲线, 并将其分为快速、慢速和稳定增 长3个阶段, 且气泡直径与时间呈幕函数关系. 鉴于其分段特性, 推荐采用分段预测模型. 发现了气泡脱离直径及 频率随热流增大而增大, 气泡脱离形状随热流增大而呈现球型、粗球型和不规则形状的变化. 还观察到气泡合并, 轨迹变化, 附加运动和流型变化等现象, 并分析讨论了其形成机理, 发现系统压力、加热壁面性质液体物性对气泡 的行为特性有较大影响. 相比文献中的常温液体, 乙烷气泡生长周期有差异, 其脱离形状有椭球型及不规则形状, 且气泡上升轨迹变化相对简单.

关键词气泡, 核态池沸腾, 乙烷, 生长, 脱离, 上升, 高速摄影

沸腾传热普遍存在于冰箱与空调器中的蒸发器, 化工装置中的再沸器, 核动力工程中的核反应堆及 其蒸汽发生器等, 换热器中制冷剂沸腾相变, 通过气 泡运动来加快固液两相间的热量传递, 提高传热效 率. 目前, 传统制冷剂存在严重的环境问题, 由于烃 类具有零臭氧破坏潜能, 低全球变暖潜能, 以及高的 热力学性能, 有学者提出将低温液体乙烷及其混合 物作为制冷剂替代工质之一 ${ }^{[1]}$. 同时, 乙烷也是天然 气的重要成分之一, 研究乙烷的传热性质对天然气 液化应用技术具有重要的参考价值. 液化天然气便 于储存和运输, 但在实际应用中, 可能由于环境或者 泄露等问题导致其产生不同程度的沸腾, 乙烷作为 其重要成分之一, 其沸腾特性的研究有利于运输管 道等的优化设计, 避免意外事故发生 ${ }^{[2,3]}$. 因此, 研 究乙烷池沸腾中的气泡行为对蒸发器等工业设备的
设计与优化、制冷剂替代工质以及天然气液化技术的 发展有重要意义.

在过去的几十年里, 有许多学者对池沸腾气泡 特性进行了研究. Fazel等人 ${ }^{[4]}$ 研究溶液中的气泡, 将 气泡成长分为三个阶段. 阶段一, 能量从加热壁面传 递给孔缝内未溢出的气体, 导致气泡开始生长; 阶段 二展现了气泡达到孔缝口的瞬间; 阶段三, 气泡半径 等于孔缝半径时达到最小半径. Jiang等人 ${ }^{[5]}$ 提出, 低 过热度时, 气泡生长主要依靠孔缝的蒸发传热, 称为 传热控制生长模式; 高过热度时, 孔缝及微液层同时 蒸发供给气泡生长, 但受到阻力限制, 称为惯性力控 制生长模式. Gerardi等人 ${ }^{[6]}$ 得到了水中单个气泡的生 长周期, 提出对于半球形气泡而言, 最初的生长主要 是沿加热壁面的径向生长. Lee等人 ${ }^{[7]}$ 和 Kim等人 ${ }^{[8]}$ 发 现气泡生长半径与时间呈幂函数关系. 
气泡生长到一定尺寸开始脱离加热表面. Thiagarajan等人 ${ }^{[9]}$ 在工质HFE-7100的研究中发现, 气泡 脱离频率随温度增加而增加, 脱离直径随温度的变 化并不明显. Hamzekhani等人 ${ }^{[10]}$ 在不同工质气泡脱 离直径的研究中发现, 一定热流密度下, 去离子水、乙 醇及其混合物中较容易出现球形气泡, 这是由于其 直径较小. Peyghambarzadeh等人 ${ }^{[11]}$ 池沸腾研究发现, $\mathrm{NaCl}$ 溶液中气泡形状基本为球形, $\mathrm{KCl}$ 和 $\mathrm{KNO}_{3}$ 溶液 中出现了扁圆、半球和不规则形状. Kim等人 ${ }^{[12]}$ 发现 压力影响气泡脱离特征.

气泡的运动行为非常复杂, 在高热流密度下表 现得尤为明显. Dhir等人 ${ }^{[13]}$ 和Warrier等人 ${ }^{[14]}$ 在全氟 正乙烷的单气泡及多气泡实验中发现, 大热流密度 下, 大气泡在脱离前会不断吸收周围的小气泡形成 更大的气泡. McHale等人 ${ }^{[15]}$ 研究抛光表面低热流下 FC-77中气泡的上升过程发现, 忽略合并的加速影 响, 脱离后气泡速率维持在一个相对稳定的状态, 且 液体流动会引起同一成核点气泡产生壁面滑移. Magnaudet和Eames ${ }^{[16]}$ 发现, 与类球形和球帽形气泡 不同, 中等尺寸的气泡除了上升之外, 还存在轨道不 稳定性, 即“刚体”型的滚动, 或者沿之字形、螺旋形 轨迹的运动.

虽然之前已有学者对水、乙醇、电解质等常温液 体中的气泡行为进行了详细的研究, 但关于低温液体 如乙烷等的池沸腾气泡行为方面的研究还极为缺乏, 且大多只涉及脱离直径和频率的变化规律. Gong等 人 ${ }^{[17]}$ 对乙烷、异丁烷及其混合物进行了核态池沸腾的 可视化研究, 但主要观察了热流密度对气泡脱离直径 和频率的影响; Zhao等人 ${ }^{[18]}$ 进行了 R14全池沸腾曲线 研究, 通过气泡图象对热流密度与汽化核心密度进行 了定性分析, 但并未对气泡行为有更深人的探索.

虽然目前已有大量关于池沸腾传热特性的研究, 但对于乙烷气泡行为的相关研究还极为缺乏. 为了 了解乙烷气泡行为规律, 本文研究了其在水平铜表 面饱和核态池沸腾中的气泡行为特性. 对研究沸腾 气泡形成机理、乙烷物性对沸腾机理的影响以及相关 工业应用有重要的参考价值. 同时, 本文提供的气泡 动力学数据可以为本工况下沸腾模型的建立和发展 提供基础依据.

\section{1 实验装置}

图1为本文可视化池沸腾实验系统示意图. 该实

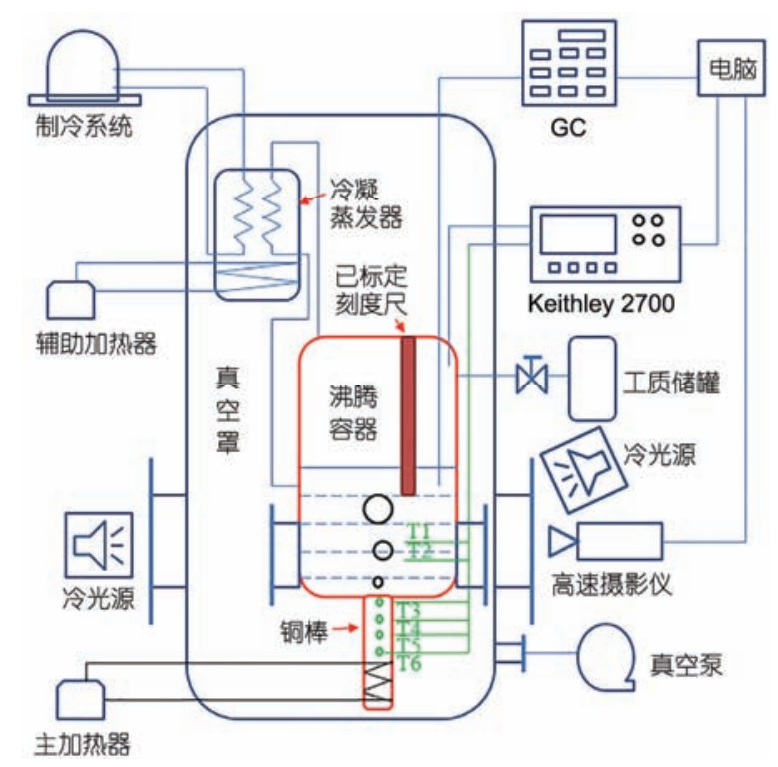

图 1 (网络版彩色)可视化池沸腾实验系统示意图

Figure 1 (Color online) Visual pool boiling experiment system diagram

验装置主要由可视化沸腾容器、加热系统(主、辅加 热器)、制冷系统、数据及图像采集系统以及真空绝 热系统5个部分组成. 加热和制冷系统控制可视沸腾 容器内的实验液体达到并保持在实验设定压力下的饱 和沸腾状态, 加热壁面为圆柱体铜棒上表面. 数据采 集系统采集温度和压力两个参数的实验数据, 作为加 热系统的反馈装置. 图像采集系统通过高速摄影仪实 时观测并记录加热壁面上的气泡行为. 实验中, 高速 摄影采集的图像及图片的分辨率均为 $960 \times 720$ pixels, 采样率为 $2619 \mathrm{pps}$, 曝光时间为 $260 \mu \mathrm{s}$, 其触发采用 后置触发器. 另外, 为了较为精确地测量气泡直径等 尺寸, 本文在沸腾池中央悬挂刻度尺作为测量参照 物. 刻度尺已在北京市计量检测科学研究院进行标 定, 其长度测量的最大不确定度为 $0.06 \mathrm{~mm}$.

\section{2 气泡特性分析与讨论}

本文进行了 $0.2 \mathrm{MPa}$ 工作压力下乙烷的饱和核态 池沸腾实验, 热流密度范围为14.65 80.79 $\mathrm{kW} \mathrm{m}$. 利用高速摄影仪从沸腾池侧面对气泡的动态行为进 行观测图像记录. 根据实验中的气泡特性, 分别从气 泡的生长、脱离和上升 3 个过程进行分析.

\section{1 气泡生长过程}

观察若干气泡发现, 尽管气泡生长过程具有很 
大的随机性和不确定性, 但是其生长过程及变化趋 势具有一致性, 故本文选取有代表性的气泡进行重 点分析. 图2(a)是沸腾表面气泡生长的不同阶段的示 意图, 图中展现了表面孔缝中气泡开始形成、冒出孔 缝以及进一步膨胀的过程, 用虚线进行区分, 机械表 面形成的凹坑通常接近雉形, 且实验中气泡以半球 形式生长. 图 2(b) 是低热流下单个气泡的生长周期 图, 由于无法观测到铜棒凹缝内部, 故取气泡脱离作 为时间节点. 时间 $t=0 \mathrm{~ms}$, 气泡脱离加热壁面; $0 \sim$ $3.05 \mathrm{~ms}$ 内, 壁面上没有气泡; $t=11.06 \mathrm{~ms}$, 气泡再次 脱离加热壁面. 气泡的等待周期为 $3.05 \mathrm{~ms}$, 生长周期 为 $11.06 \mathrm{~ms}$, 脱离频率约为 $90 \mathrm{~Hz}$. 文献中提到, 当压 力 $p=0.1 \mathrm{MPa}$, 热流密度 $q=20.4 \mathrm{~kW} \mathrm{~m}$ 时, R11-R113 混合物的气泡生长周期为 $9.45 \mathrm{~ms}^{[19]}$; 当 $p=0.1 \mathrm{MPa}$, $q=20 \mathrm{~kW} \mathrm{~m}^{-2}$ 时, FC-72的气泡生长周期为 $18 \mathrm{~ms}^{[20]}$; 当 $p=0.085 \mathrm{MPa}, q=23 \mathrm{~kW} \mathrm{~m}^{-2}$ 时, 水的气泡生长周期不 低于 $200 \mathrm{~ms}^{[21]}$. 由此可知, 系统压力及液体物性对生 长周期有较大影响. 对 3 个典型生长气泡进行测量, 得到弦长及拱高参数数据, 再通过几何关系式计算 气泡直径 ${ }^{[22]}$. 气泡直径、弦长及拱高随时间变化的曲 线如图3所示.

由图3可知, 乙烷中气泡直径在整个生长周期中 呈上升趋势, 前期增速快, 后期趋于平缓, 存在一定 的等待周期. 本文选取典型工况的一组气泡生长特 性数据, 记录气泡直径随时间的变化情况, 将气泡生 长周期分为三个阶段. 第一阶段: 快速生长期, 0 $4.2 \mathrm{~ms}$. 气泡在凹坑中生长, 球心角保持不变, 半径 沿壁面增大, 直至可视. $t=3.05 \mathrm{~ms}$, 气泡冒出孔缝, 可视部分呈扁平状. 此时为气泡的生长初期, 气泡直
径、弦长及拱高都快速增长. 第二阶段: 慢速生长期, 4.2 8.39 ms. 在这个阶段, 气泡突破孔缝禁锢, 在加 热面上继续生长, 体积持续增加. 此时为气泡的生长 中期, 气泡直径、弦长及拱高保持增长, 但增速减缓. 第三阶段: 稳定生长期, 8.39 11.06 ms. $t=8.39 \mathrm{~ms}$ 后, 气泡呈半球状, 弦长达到峰值, 直径趋于稳定, 预示 着气泡扩张性生长基本完成. 此时为气泡的生长后 期, 气泡继续长大, 从半球到球形, 直径基本不再变 化, 弦长减小, 拱高增加, 体积增加. $t=11.06 \mathrm{~ms}$, 气 泡脱离加热壁面. 分析若干气泡的生长曲线发现, 气 泡生长存在明显的分段特性, 数据拟合曲线与时间 的幂函数吻合度较高, 因此, 本文认为气泡直径为时 间的幕函数, 且分段预测模型精度更高.

\section{2 气泡脱离过程}

( i ) 脱离直径及频率. 图4是不同热流密度下 的乙烷气泡图像, 由图可知, 加热壁面越靠近中心, 气泡越小而稀疏; 越远离中心, 气泡越大而密集. 这 说明中心脱离频率大, 等待周期短, 即圆形铜加热壁 面圆周上的热流密度相对圆心更为集中, 与李彦鹏 和白博峰 ${ }^{[23]}$ 的模拟结果相似. 本文认为铜棒抛光后 表面粗楉度不均匀以及加热棒本身的导热性质是导 致这一现象的重要因素. 图4(a)气泡小而稀疏, 图 4(c)气泡大而密集, 这说明热流密度越大, 气泡脱离 直径越大, 脱离频率也越大.

(ii) 脱离形状. Hamzekhani等人 ${ }^{[10]}$ 研究发现, 水和乙醇中的气泡基本呈球形, 本文对乙烷的研究 显示出不同的特性，其气泡脱离形状随热流密度的 变化而改变. 图5 是乙烷气泡脱离形状图, 由图可知, (a)

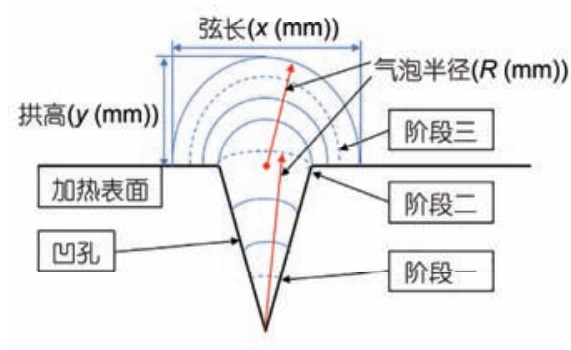

(b)

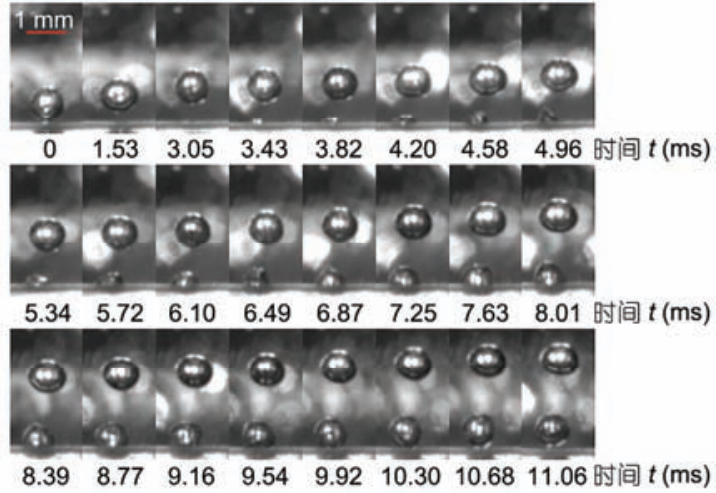

图 2 (网络版彩色)气泡生长图. (a) 沸腾表面气泡生长的不同阶段的示意图; (b) 乙烷气泡生长周期图, $q=21.02 \mathrm{~kW} \mathrm{~m}^{-2}$

Figure 2 (Color online) Diagrams of bubble grows. (a) Diagram of bubble grows at different stages in boiling surface; (b) bubble growth cycle in ethane, $q=21.02 \mathrm{~kW} \mathrm{~m}^{-2}$ 
(a)

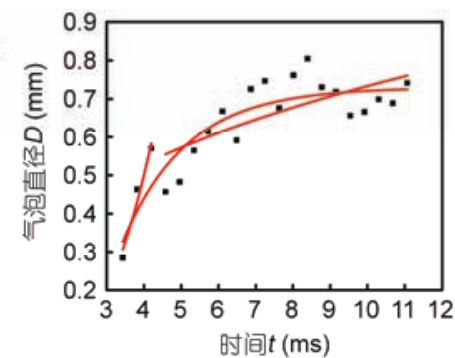

(b)

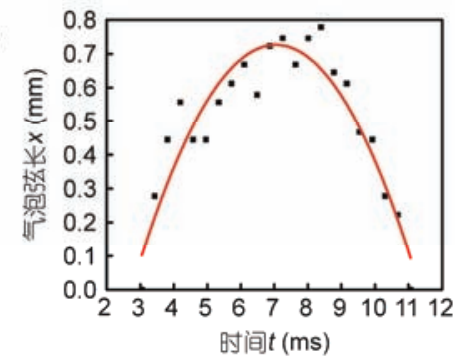

(c)

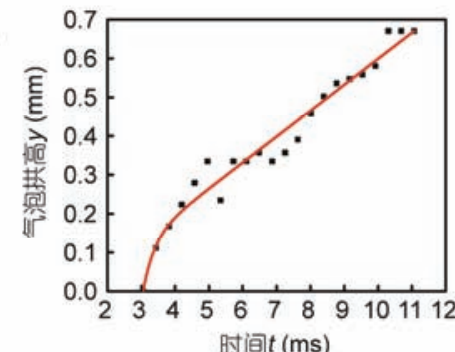

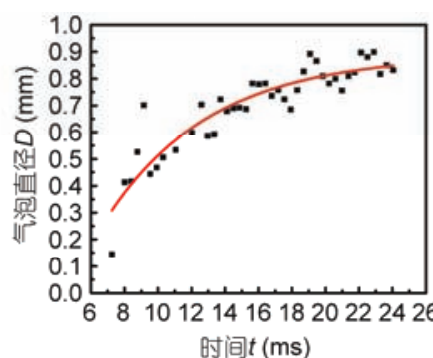
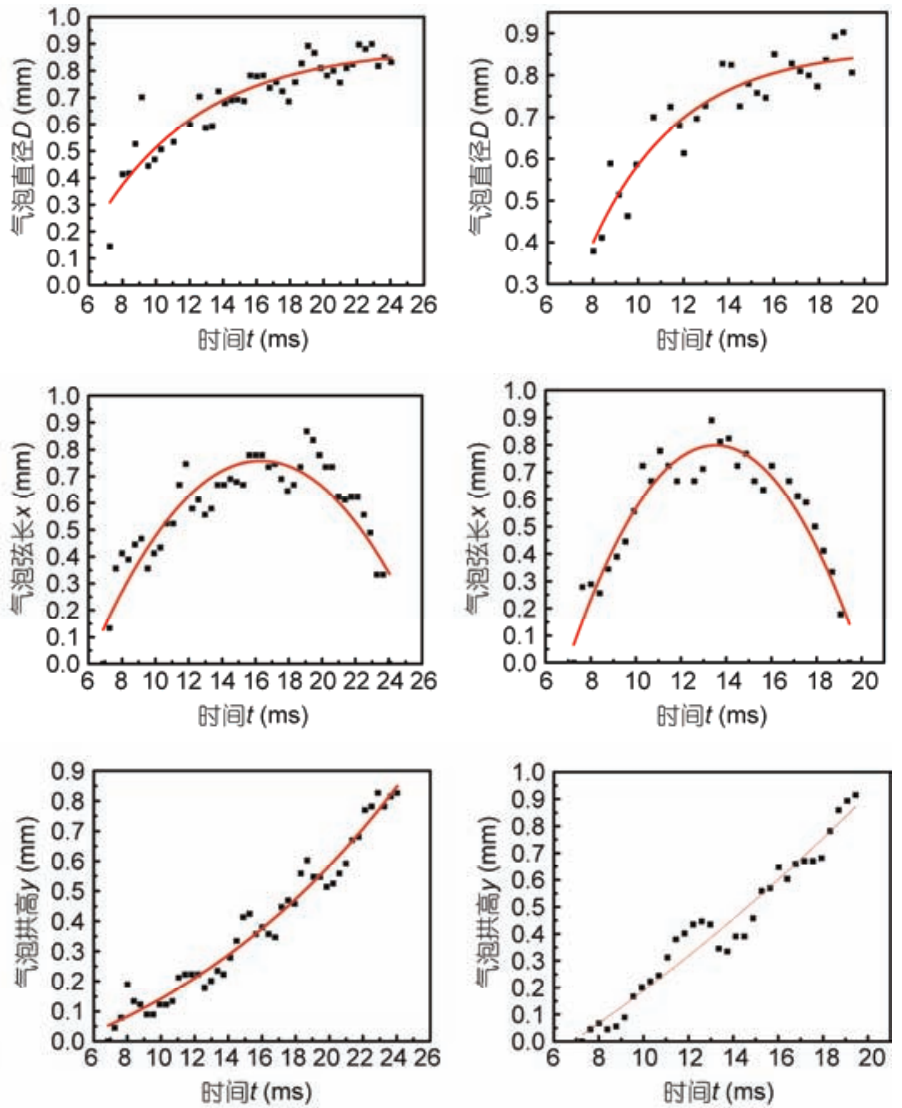

图 3 (网络版彩色)气泡曲线图. (a) 气泡直径随时间变化的曲线; (b) 气泡加热壁面弦长随时间变化的曲线; (c) 气泡拱高随时间变化曲线

Figure 3 (Color online) The curve of the bubble. (a) The curves of the bubble diameter changes with time; (b) the curves of the bubble chord length changes with time in heat wall; (c) the curves of the bubble arch height changes with time
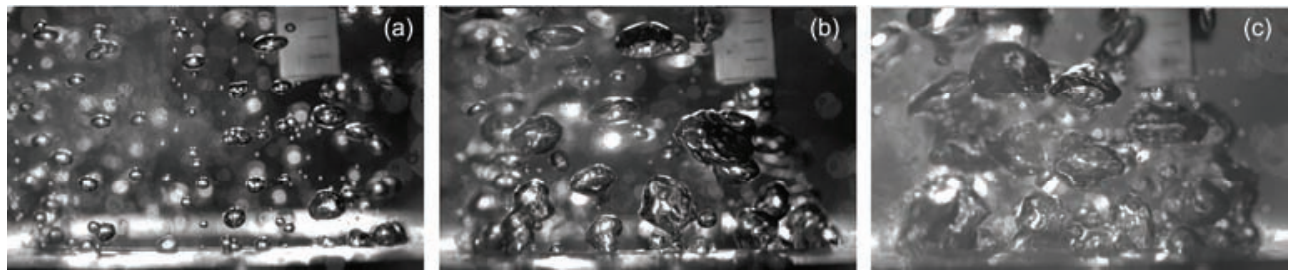

图 4 不同热流密度下的乙烷气泡图像. (a) $q=14.65 \mathrm{~kW} \mathrm{~m}^{-2}$; (b) $q=43.51 \mathrm{~kW} \mathrm{~m}^{-2}$; (c) $q=80.79 \mathrm{~kW} \mathrm{~m}^{-2}$

Figure 4 Bubble images at different heat flux in ethane. (a) $q=14.65 \mathrm{~kW} \mathrm{~m}^{-2}$; (b) $q=43.51 \mathrm{~kW} \mathrm{~m}^{-2}$; (c) $q=80.79 \mathrm{~kW} \mathrm{~m}^{-2}$
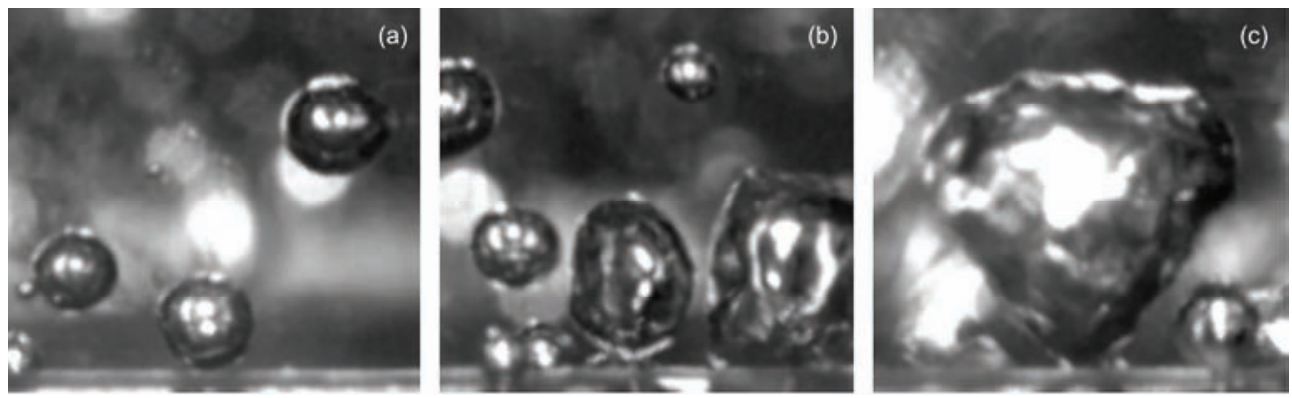

图 5 乙烷气泡脱离形状图. (a) $q=21.02 \mathrm{~kW} \mathrm{~m}^{-2}$, 球形; (b) $q=29.30 \mathrm{~kW} \mathrm{~m}^{-2}$, 椭球形; (c) $q=80.79 \mathrm{~kW} \mathrm{~m}^{-2}$, 不规则形状

Figure 5 Departure bubble shapes in ethane. (a) $q=21.02 \mathrm{~kW} \mathrm{~m}^{-2}$, spherical; (b) $q=29.30 \mathrm{~kW} \mathrm{~m}^{-2}$, vertical ellipsoid; (c) $q=80.79 \mathrm{~kW} \mathrm{~m}{ }^{-2}$, irregular shape 
气泡在脱离时有3种近似的脱离形状. 当热流密度较 低时, 如图 5(a)所示, 气泡呈明显的球形, 气泡直径 小, 受力均匀, 气液界面波动小, 呈对称状; 当热流 密度增加, 如图 5(b)所示, 气泡呈长轴在垂直方向的 椭球形, 此时浮力占主导地位, 气泡被拉长, 沸腾接 触角增加; 热流密度进一步增加, 如图5(c)所示, 气 泡呈不规则形状, 较大的过热度促使液体大量蒸发 进人气泡, 气泡体积快速增加, 在浮力作用下形成头 重脚轻的形状, 沸腾接触角进一步增加. 由此可见, 由液体物质及壁面条件共同决定的某些性质, 如接 触角, 会受到沸腾过程的影响.

(iii) 气泡合并. 刀彦华等人 ${ }^{[24]}$ 发现, 低热流密 度下, 气泡生长清晰明显; 高热流密度下, 气泡行为 呈现不规律性. 沸腾气泡间的相互干涉影响沸腾气 泡的脱离直径及频率, 其中气泡合并是造成液体扰 动、加快固液热量传递的重要原因之一. 其一, 合并 影响增长周期和等待周期. 图6(a)展示了不同成核点
气泡之间的抽吸现象, 右侧已脱离气泡斜向吞并了 增长中的左侧气泡, 导致左侧气泡加速脱离, 缩短了 增长周期, 但延长了新一轮气泡的等待周期, 因此增 加了气泡生长周期的不确定性.

其二, 加热壁面存在水平滑移, 如图6(b)所示. 图中右端气泡向左侧移动, 其右侧出现移动尾迹, 接 触角变大. 这是由于两个气泡间距小, 表面张力不足 导致界面合并，同时，惯性力的差异使其中一个气泡 远离原成核点. 这个现象在高热流密度条件下频繁 发生, 液体过热引起的物性变化是造成这一现象的 原因之一.

其三, 气泡合并在壁面留下小尾巴, 形成沸腾池 “挂杯”现象, 如图6(c)所示. 图中合并的两个气泡在 脱离过程中被拉长, 形成细长颈部, 液相应力作用使 气泡从颈部截断, 上半部分继续上升, 下半部分滞留 在加热壁面, 作为下一轮生长周期的初始气泡. 这是 由于表面张力不足引起的气泡断裂, 会影响气泡生 (a)

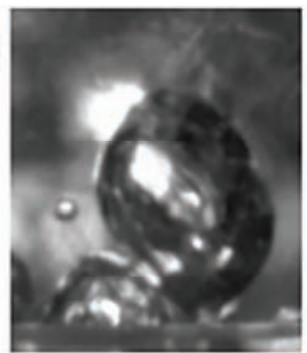

(b)

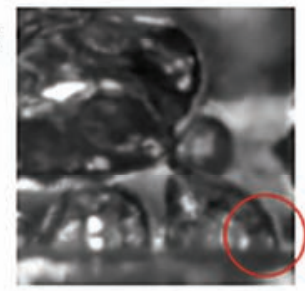

(c)

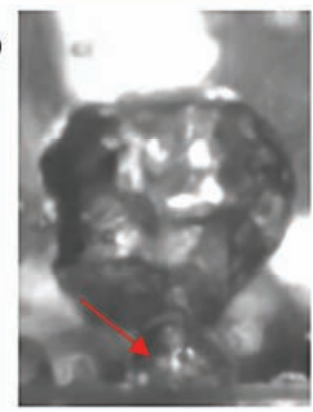

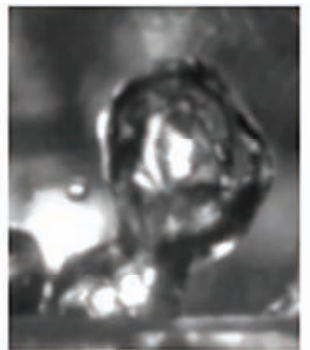
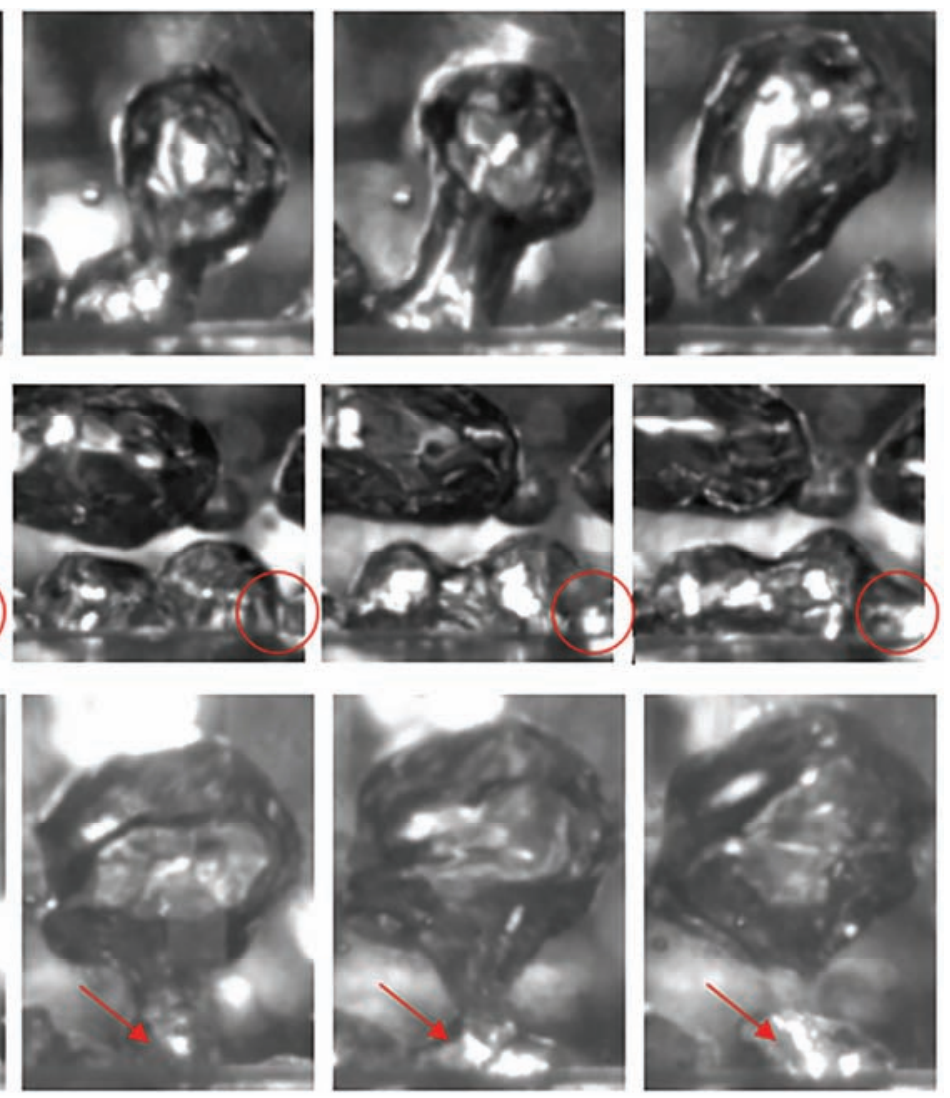

图 6 (网络版彩色)气泡合并. (a) 乙烷气泡的抽吸现象, $q=43.51 \mathrm{~kW} \mathrm{~m}^{-2}$; (b) 乙烷气泡的水平滑移现象, $q=43.51 \mathrm{~kW} \mathrm{~m}$; (c) 乙烷气泡的“挂 杯”现象, $q=73.68 \mathrm{~kW} \mathrm{~m}^{-2}$

Figure 6 (Color online) Bubble coalescence. (a) Suction phenomenon of bubbles in ethane, $q=43.51 \mathrm{~kW} \mathrm{~m}^{-2}$; (b) horizontal slip of bubbles in ethane, $q=43.51 \mathrm{~kW} \mathrm{~m}^{-2}$; (c) the "hanging cup" phenomenon of bubbles in ethane, $q=73.68 \mathrm{~kW} \mathrm{~m}^{-2}$ 
长周期.

近壁面气泡行为是影响换热的重要环节之一, 本文研究发现, 系统压力、加热壁面性质如表面粗糙 度、液体物性如接触角和表面张力等是造成气泡运动 差异的重要原因, 因此本文认为与气泡脱离相关的 机理研究应充分考虑这些因素的影响.

\section{3 气泡上升过程}

(i ) 气泡轨迹. Magnaudet等人 ${ }^{[16]}$ 观测到水中 气泡轨迹为之字形或螺旋形, 而本文乙烷运动轨迹 则较为简单. 低热流密度下, 小气泡运动轨迹基本呈 直线上升; 较高热流密度时, 由于气泡运动对液体扰 动影响, 大气泡上升轨迹具有非对称性. 图7(a)是相 继生长的 3 个大气泡的运动轨迹图. 由图可知, 气泡 在上升过程中呈现向中心聚拢的趋势, 气泡运动关 于整个沸腾池中轴线对称, 本文认为这是由于中轴 线气泡小空间大, 远离中轴线气泡大空间小, 周边气 泡的挤压扰动等气泡之间的相互作用, 或者因为中心 线附近的向上的对流最强, 抽吸四周的气泡至中心.

(ii) 气泡附加运动. 大气泡同时存在不规则变 形和气液界面振荡, 这与气泡所受浮力、表面张力以 及黏性阻力的合力有关 ${ }^{[25,26]}$. 图7(a)中气泡 1 和 2 形变

(a)

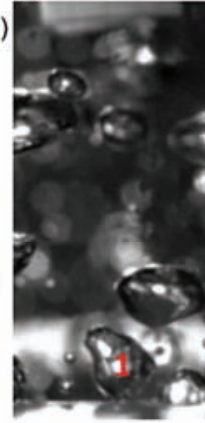

(b)

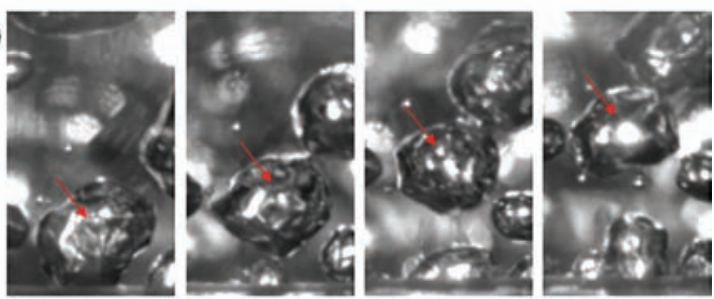

图 7 (网络版彩色)气泡轨迹及其附加运动. (a) 乙烷气泡向圆心聚拢 现象, $q=21.02 \mathrm{~kW} \mathrm{~m}^{-2}$; (b) 乙烷大气泡的附加运动, $q=43.51 \mathrm{~kW} \mathrm{~m}^{-2}$

Figure 7 (Color online) Bubble trail and its additional movements. (a) The phenomenon of bubbles converging to the circle center in ethane, $q=21.02 \mathrm{~kW} \mathrm{~m}^{-2}$; (b) additional movements of big bubbles in ethane, $q=43.51 \mathrm{~kW} \mathrm{~m}^{-2}$
明显，主要表现为水平或垂直方向的压缩和膨胀. 脱 离瞬间气泡多呈球形, 相对比较饱满, 由于气泡此时 没有明显位移, 受力相对比较均匀, 因此形状较为规 整; 脱离后气泡很快变得扁平, 呈水平方向发展的椭 球形，因为气泡脱离后，在浮力作用下加速上升，液 体阻力导致气泡上接触面积增加; 气泡继续上升恢 复到球形, 此时黏性阻力随着气泡上升速度的增加 而增加, 逐渐与浮力达到一个相对平衡状态. 观察图 7(b)中大气泡的附加运动，发现其气液界面振荡明 显，呈波纹状，随时间无规律变化，这是因为其受到 合力的综合影响. 王焕然等人 ${ }^{[27]}$ 和李彦鹏等人 ${ }^{[28]}$ 均发 现黏性流体中气泡在上升过程中存在形状变化. 徐畑 等人 ${ }^{[29]}$ 提出, 气泡形状改变造成尾迹扰动，导致其运 动过程中形状继续改变, 使气泡随机运动加剧.

（iii）上升流型. 生成的气泡在上升过程中无明 显的向非沸腾区域扩张的现象，此时池沸腾可视为 垂直管道中流速较低的流动沸腾. 将沸腾池中充满 气泡的区域看作流束，同一成核孔生长的气泡形成 流线，此时沸腾池表现出明显的“流型”. 由于池沸腾 是在原来静止的液体中发生的沸腾现象，气泡动能 相对较小，流速低，因此，主要表现出泡状流和段塞 流两种流型. 图8(a)为泡状流型, 此时依赖于气泡扰 动的液相流速较低，随着热流密度增加，气相流速从

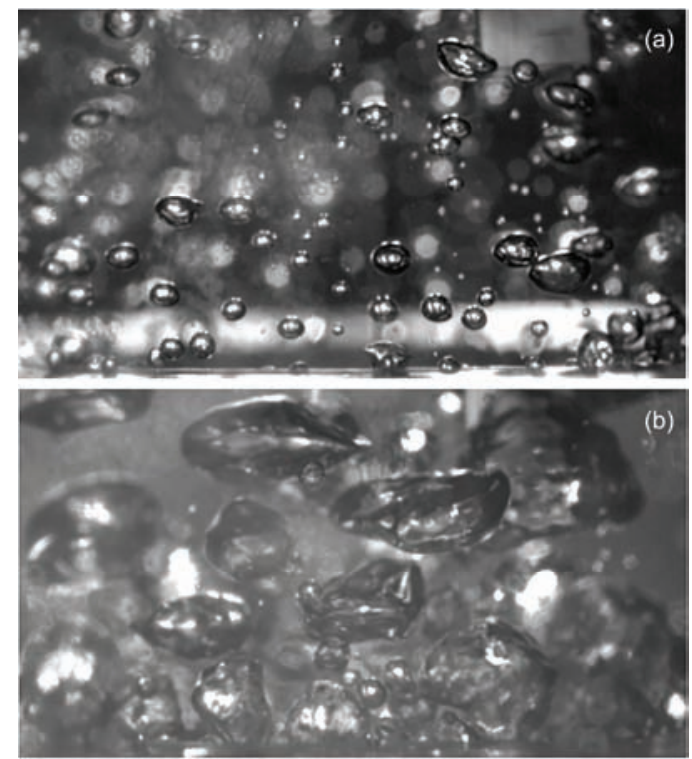

图 8 乙烷气泡流型图. (a) $q=14.65 \mathrm{~kW} \mathrm{~m}^{-2}$, 泡状流型; (b) $q=80.79$ $\mathrm{kW} \mathrm{m}{ }^{-2}$, 段塞流型

Figure 8 Bubble flow pattern in ethane. (a) $q=14.65 \mathrm{~kW} \mathrm{~m}^{-2}$, bubble flow pattern; (b) $q=80.79 \mathrm{~kW} \mathrm{~m}^{-2}$, slug flow pattern 
零缓慢增加, 分散为众多不连续的小气泡. 图8(b)为 段塞流型, 热流密度进一步增大, 气相流量持续增 加, 气泡间相互碰撞与合并的频率增加, 小气泡合并 成较大的帽型泡, 几乎覆盖住整个加热壁面. 由此可 见, 当热流密度进一步增加, 可能出现弹状流或 Taylor泡.

远壁面气泡行为也是影响换热的重要环节之一, 本文研究发现, 热流越大, 气泡的轨迹变化和附加运 动对液体的扰动作用越强, 可知固液间换热系数也 越大, 因此本文认为强化换热相关的机理研究应充 分考虑气泡上升位移、速度以及加速度等的影响. 流 型的引人为池沸腾研究提供了新视角.

\section{3 结论}

本文主要进行了不同热流密度条件下乙烷纯质 的饱和核态池沸腾传热的可视化实验, 研究了沸腾 过程中的气泡行为特性, 获得了大量的沸腾传热实 验数据和气泡行为图像. 通过对乙烷气泡的生长、脱 离以及上升过程 3 个方面进行分析, 可总结归纳出以 下结论.
（1）得到乙烷单个气泡生长周期图. 根据气泡生 长过程中直径随时间的变化关系, 将乙烷的生长过 程分为快速、慢速以及稳定生长 3 个阶段, 且气泡直 径为时间的幕函数. 气泡生长过程具有明显的分段 特性, 推荐采用分段预测模型.

（2）沸腾池气泡呈现轴对称不均匀分布的特性; 相对常温液体, 乙烷气泡的脱离形状还具有椭球型 及不规则形状; 沸腾气泡间相互干涉强烈.

（3）小气泡沿直线上升; 大气泡则存在向中心聚 拢的轨迹变化和剧烈的气液界面波动等附加运动, 同时, 热流越大, 气泡运动对液体的扰动作用越强, 固液间换热系数也越大, 但相比常温液体轨迹变化 相对简单; 观测到单个气泡相继出现球形-椭球-球形 的形状变化, 且气泡上升中主要有泡状流和段塞流 两种流型.

(4) 气泡行为是影响换热的重要环节之一, 系统 压力、加热壁面性质如表面粗粘度、液体物性如接触 角和表面张力等差异对气泡的行为特性有较大影响, 因此本文认为考虑了压力、壁面及物性参数的传热预 测关联式更显全面.

\section{参考文献}

1 Gong M Q, Sun Z H, Wu J F, et al. Performance of R170 mixtures as refrigerants for refrigeration at $-80^{\circ} \mathrm{C}$ temperature range. Int J Refrig, 2009, 32: 892-900

2 Liu Y. Dangers and safeguards of LNG (in Chinese). Natur Gas Ind, 2004, 24: 105-107 [刘勇. 液化天然气的危险性与安全防护. 天然 气工业, 2004, 24: 105-107]

3 Wang Q S, Wu M, Guan X Y, et al. Discussion on the leakage problem of liquefied natural gas (in Chinese). Contemporary Chem Ind, 2012, 9: 892-894 [王秋莎, 吴明, 官学源, 等. 液化天然气的泄漏问题. 当代化工, 2012, 9: 892-894]

4 Fazel S A A, Shafaee S B. Bubble dynamics for nucleate pool boiling of electrolyte solutions. J Heat Transfer, 2010, 132: 0815021

5 Jiang Y Y, Osada H, Inagaki M, et al. Wall thermal conductivity effects on nucleation site interaction during boiling-An experimental study. In: Proceedings of the 14th International Heat Transfer Conference. Washington, 2010. 135-160

6 Gerardi C, Buongiorno J, Hu L W, et al. Study of bubble growth water pool boiling through synchronized, infrared thermometry and high-speed video. Int J Heat Mass Transf, 2010, 53: 4185-4192

7 Lee H C, Kim J, Oh B D, et al. Single bubble growth in saturated pool boiling of binary mixtures. Int J Multiphase Flow, 2004, 30: 697-710

8 Kim J, Oh B D, Kim M H. Experimental study of pool temperature effects on nucleate pool boiling. Int J Multiphase Flow, 2006, 32: 208-231

9 Thiagarajan S J, Yang R, King C, et al. Bubble dynamics and nucleate pool boiling heat transfer on microporous copper surfaces. Int J Heat Mass Transf, 2015, 89: 1297-1315

10 Hamzekhani S, Maniavi Falahieh M, Akbari A. Bubble departure diameter in nucleate pool boiling at saturation: Pure liquids and binary mixtures. Int J Refrig, 2014, 46: 50-58

11 Peyghambarzadeh S M, Hatami A, Ebrahimi A, et al. Photographic study of bubble departure diameter in saturated pool boiling to electrolyte solutions. Chem Ind Chem Eng Q, 2014, 20: 143-153

12 Kim J, Kim M H. On the departure behaviors of bubble at nucleate pool boiling. Int J Multiphase Flow, 2006, 32: 1269-1286

13 Dhir V K, Warrier G R, Aktinol E, et al. Nucleate pool boiling experiments (NPBX) on the international space station. Microgravity Sci Technol, 2012, 24: 307-325 
14 Warrier G R, Dhir V D, Chao D F. Nucleate Pool Boiling experiment (NPBX) in microgravity: International space station. Int J Heat Mass Transf, 2015, 83: 781-798

15 McHale J P, Garimella S V. Bubble nucleation characteristics in pool boiling of a wetting liquid on smooth and rough surfaces. Int J Multiphase Flow, 2010, 36: 249-260

16 Magnaudet J, Eames I. The motion of high-reynolds-number bubble in inhomogeneous flows. Annu Rev Fluid Mech, 2000, 32: 659-708

17 Gong M Q, Wu Y F, Ding L, et al. Visualization study on nucleate pool boiling of ethane, isobutane and their binary mixtures. Exp Therm Fluid Sci, 2013, 51: 164-173

18 Zhao C, Gong M Q, Ding L, et al. An experimental investigation on the entire pool boiling curve of R14 under 0.1 MPa pressure. Int J Refrig, 2014, 41: 164-170

19 Diao Y H, Zhao Y H, Wang Q L. Visualization of bubble dynamics for pool boiling of binary refrigerant mixture R11-R113. Chin J Chem Eng, 2006, 14: 149-157

20 Moghaddam S, Kiger K. Physical mechanisms of heat transfer during single bubble nucleate boiling of FC-72 under saturation conditions-I. Experimental investigation. Int J Heat Mass Transf, 2009, 52: 1284-1294

21 Kenning D B R, Kono T, Wienecke M. Investigation of boiling heat transfer by liquid crystal thermography. Exp Therm Fluid Sci, 2001, 25: $219-229$

22 Matkovič M, Končar B. Bubble departure diameter prediction uncertainty. Sci Technol Nucl Ins, 2012, 2012: 863190

23 Li Y P, Bai B F. Numerical simulation of bubble formation and rise from submerged or if ices in viscous liquid (in Chinese). Chin J Hydrodyn, 2006, 21: 660-666 [李彦鹏, 白博峰. 气泡从浸没孔中生成与上升的数值模拟. 水动力学研究与进展, 2006, 21: 660-666]

24 Diao Y H, Zhao Y H, Wang Q L. Bubble dynamics and heat transfer mechanism of pool boiling of R-113 (in Chinese). J Chem Ind Eng, 2005, 56: 227-234 [ᄀ彦华，赵耀华，王秋良. R-113 池沸腾气泡行为的可视化及传热机理. 化工学报, 2005, 56: 227-234]

25 Johnson Jr M A, Peña J D L, Mesler R B. Bubble shapes in nucleate boiling. A1ChE J, 1966, 12: 344-348

26 Chen H Z, Chen G F, Zou X, et al. Experimental investigations on bubble departure diameter and frequency of methane saturated nucleate pool boiling at four different pressures. Int J Heat Mass Transf, 2017, 112: 662-675

27 Wang H R, Li Y P, Yang D, et al. On the shape feature of a single bubble rising in viscous liquids (in Chinese). J Eng Thermophys, 2009, 30: 1492-1494 [王焕然, 李彦鹏, 杨栋, 等. 黏性液体中单个气泡上升的形状特性. 工程热物理学报, 2009, 30: 1492-1494]

28 Li Y P, Zhang Q L, Bai B F. A direct numerical simulation of neighboring air-bubble rising process in a vertical channel (in Chinese). J Eng Thermal Energy Power, 2007, 22: 375-379 [李彦鹏, 张乾隆, 白博峰. 竖直通道内相邻气泡对上升的直接数值模拟. 热能动力 工程, 2007, 22: 375-379]

29 Xu J, Wang T, Yang B, et al. The measurement and analysis of motion behavior of bubbles in calm water (in Chinese). Chin J Hydrodyna, 2008, 23: 709-714 [徐炣, 王粀, 杨波, 等. 静止水下气泡运动特性的测试与分析. 水动力学研究与进展, 2008, 23: 709-714] 


\title{
Bubble growth, departure and rising of ethane at nucleate pool boiling condition
}

\author{
Yuan Yao ${ }^{1,2}$, Maoqiong Gong ${ }^{1,2^{*}}$, Hanzhi Chen ${ }^{1,2}$, Gaofei Chen ${ }^{1}$, Xin Zou ${ }^{1}$, \\ Xueqiang Dong ${ }^{1} \&$ Jun Shen ${ }^{1,2}$ \\ ${ }^{1}$ Key Laboratory of Cryogenics, Technical Institute of Physics and Chemistry, Chinese Academy of Sciences, Beijing 100190, China; \\ ${ }^{2}$ University of Chinese Academy of Sciences, Beijing 100049, China \\ * Corresponding author, E-mail: gongmq@mail.ipc.ac.cn
}

Boiling heat transfer exists in many industrial heat exchangers such as the evaporator of the refrigerator and the air conditioner, the reboiler of the chemical equipment and steam generator of the nuclear reactor. In the process of boiling, bubble movement can speed up the heat transfer between liquid and solid, leading to the improvement in heat transfer efficiency. Traditional refrigerants used in the industrial facilities have serious environmental problems, therefore, new substitutes are needed. Hydrocarbons are good alternatives. Ethane was suggested as one component of a mixedrefrigerant for its zero ozone depletion potential, low global warming potential and high thermodynamic properties. Therefore, it is important to investigate the bubble behavior of ethane in saturated nucleate pool boiling to design and optimize the industrial equipment like evaporator, improve natural gas liquefaction technology, and research characteristics of heat transfer and multiphase flow as well. Although there are a lot of researches on the heat transfer characteristics of pool boiling, the research on the bubble behavior in ethane is still lacking. In this paper, visualization experiments on the pool boiling heat transfer characteristics of ethane were carried out at $0.2 \mathrm{MPa}$. The heat fluxes varied from $14.65 \mathrm{~kW} \mathrm{~m}^{-2}$ to $80.79 \mathrm{~kW} \mathrm{~m}^{-2}$. Boiling occurred on the upward facing side of a smooth vertical copper cylinder with $20 \mathrm{~mm}$ diameter, connected to a DC power supply to control the heat flux on the surface. The measured roughness of the surface was $68.1 \mathrm{~nm}$ (root mean square average of the height deviations) and $50.7 \mathrm{~nm}$ (the arithmetic average of the absolute values of the surface height deviations). Acquisition of the temperature and pressure was accomplished by using a Keithley 2700 and six thermocouples. The experimental apparatus has a steel ruler inside the pool as the reference length to measure the bubble sizes and the maximum uncertainty for length measurement is $0.060 \mathrm{~mm}$. Some conclusions can be drawn. (1) According to the change of diameter with time, the growth process was divided into three stages. The bubble growth process has obvious segmentation characteristics, and piecewise prediction models are recommended. (2) The bubbles in boiling pool exhibit the characteristics of axial symmetry and uneven distribution; the shape of separation of ethane bubbles has ellipsoidal and irregular shapes relative to normal temperature liquids. (3) There were trail changes and additional movements of large bubbles. Compared to normal temperature liquids, the trail changes were relatively simple; and the bubbles are bubbly and slug flow of two flow regimes. (4) System pressure, heating wall properties like surface roughness, liquid properties like contact angle and surface tension have an important influence on bubble behavior. This paper suggests that the heat transfer prediction equation should consider them.

bubble, nucleate pool boiling, ethane, growth, departure, rising, high-speed camera

doi: $10.1360 /$ N972017-00579 